\title{
EMOCJE EPISTEMICZNE I NORMATYWNOŚĆ ALBO $O$ TYM JAK POKOCHAĆ TEORIĘ ZNACZENIA
}

\begin{abstract}
Streszczenie. Celem artykułu jest omówienie zagadnienia treści i funkcji tzw. emocji epistemicznych, takich jak poczucie poprawności i niepoprawności. Twierdzę, że odpowiednie wyjaśnienie tych ostatnich powinno uwzględnić ich nie-metareprezentacyjny, niedykursywny i pozbawiony kryteriów charakter. W nawiązaniu do zagadnienia tzw. normatywności pierwotnej i problemu kierowania się regułą twierdzę, że możemy powiązać emocje epistemiczne z teorią znaczenia i argumentuję, że pewna klasa emocji epistemicznych, tj. poczucie poprawności i niepoprawności, stanowi warunek konieczny znaczenia.
\end{abstract}

Słowa kluczowe: emocje epistemiczne; normatywność pierwotna; kierowanie się regułą; treść; znaczenie

1. Poczucie błędu i poprawności. 2. Normatywność pierwotna i problem kierowania się regułą.

3. Ślepota na aspekty i przeżycie znaczenia. 4. Emocje epistemiczne i teoria znaczenia.

Nie ulega wątpliwości, że emocje odgrywają istotną rolę w poznaniu. Jako przykład można przytoczyć tzw. emocje epistemiczne (epistemic emotions), takie jak ciekawość, wątpliwość, nadzieja, lęk itp., współtworzące nastawienia sądzeniowe typu: ,jestem ciekaw, czy $p$ ”, „wątpię, że $p$ ”, „mam nadzieję, że $p$ ”, czy „obawiam się, że $p$ ”. Z drugiej strony można zaryzykować twierdzenie, że problematyka afektów stosunkowo niedawno zagościła we współczesnej analitycznej filozofii umysłu i epistemologii ${ }^{1}$. Ta relatywna nieobecność spowodowana była wciąż dominującym przekonaniem, że emocje, choć istotne w kontekstach poznawczych, nie mają natury poznawczej. Mogą one

1 Jako godne uwagi wyjątki od reguły należy przytoczyć m.in. prace Donalda Davidsona, Nelsona Goodmana i Moritza Schlicka. Por. D. Davidson, Rational animals, Dialectica 36(1982), 317-327; N. Goodman, Languages of Art. An Approach to a Theory of Symbols, 2nd edition, Indianapolis 1976; M. Schlick, Über das Fundament der Erkenntnis Erkenntnis 4 (1934), 79-99. 
wyjaśniać procesy nabywania przekonań, ale nie mogą dostarczać uzasadnień dla tych ostatnich.

Drugim powodem względnej nieobecności zagadnienia emocji epistemicznych w ogólnej refleksji epistemologicznej był i jest brak jasności dotyczącej tego, czym są te ostatnie. We współczesnej literaturze psychologicznej i filozoficznej trudno o ich jednoznaczną charakterystykę. Problem rodzi między innymi kwestia tego, jak odróżnić je od odczuć lub wrażeń (feelings) ${ }^{2}$. Nie jest również jasne, jak mają się one do innych typów odczuć czy emocji ${ }^{3}$ Wydaje się jednak, że wskazane problemy stanowią część ogólnego zamętu pojęciowego we współczesnych naukach o poznaniu, spowodowanego głównie tym, że nie dysponujemy ogólnie przyjętą i niekontrowersyjną teorią emocji ${ }^{4}$ Z pewnością moją ambicją nie jest próba rozjaśniania tego, czym są odczucia i emocje. Na potrzeby tego tekstu proponuję, żebyśmy abstrahowali od rozróżnienia na emocje i odczucia ${ }^{5}$ oraz przyjęli pewną ogólną charakterystykę emocji epistemicznych. Będę je rozumiał jako takie afekty, które dotyczą własnych stanów oraz procesów umysłowych danego podmiotu .

2 Por. M.R. Bennett, P.M.S. Hacker, Philosophical Foundations of Neuroscience, Oxford 2003.

3 Por. P. Carruthers, Are epistemic emotions metacognitive?, Philosophical Psychology (2016), 1-15; J. Dokic, Seeds of self-knowledge: noetic feelings and metacognition, w: Foundations of metacognition, ed. M.J. Beran, J.L. Brandl, J. Perner, J. Proust, Oxford 2012, 302-321; J. Proust, Is there a sense of agency for thought?, w: Mental actions and agency, ed. L. O'Brien, M. Soteriou, Oxford 2009, 253-279; S. Arango-Muñoz, The nature of epistemic feelings, Philosophical Psychology 27(2014)2, 193-211.

4 Por. A. Dąbrowski, Wpływ emocji na poznanie, Przegląd Filozoficzny - Nowa Seria 3(2012), 315-335.

5 Nawet jeżeli zasadne jest wprowadzenie rozróżnienia na emocje i odczucia epistemiczne, to w literaturze przedmiotu panuje powszechne przekonanie, że dzielą one szereg wspólnych własności.

6 Por. S. Arango-Muñoz, K. Michaelian, Epistemic feelings, epistemic emotions: Review and introduction to the focus section, Philosophical Inquiries 2(2014)1, 97-122; R. de Sousa, Epistemic feelings, w: Epistemology and emotions, ed. G. Brun et.al., New York 2016, 185-204; J. Dokic, dz. cyt. 
Powyższy opis nie pretenduje oczywiście do bycia wyczerpująca definicją. Istotne jest to, żeby - wzbogacony o naprowadzające przykłady - wyodrębniał pewne explanandum. Z punktu widzenia tego tekstu głównym pytaniem badawczym jest bowiem kwestia tego, co to znaczy oraz co sprawia, że pewna klasa emocji posiada funkcję epistemiczną ${ }^{7}$. Innymi słowy, zanim zaczniemy zastanawiać się nad pytaniem, czym są emocje poznawcze, i jak odróżnić je od wrażeń, należy, w moim przekonaniu, odpowiedzieć na bardziej podstawowe pytania dotyczące roli tych pierwszych w systemach poznawczych oraz źródeł ich własności epistemicznych. Mówiąc ściślej, główne pytanie badawcze w tym tekście brzmi: jak scharakteryzować treść emocji epistemicznych oraz jaka jest funkcja tych ostatnich w systemach poznawczych?

W swoich rozważaniach skupię się na specjalnej klasie emocji epistemicznych - poczuciu błędu oraz poczuciu poprawności ${ }^{8}$. Poruszę zagadnienie ich treści - opiszę ich nie-metareprezentacyjny oraz pozbawiony kryteriów i niedyskursywny charakter - a poprzez skonfrontowanie ich z koncepcją tzw. normatywności pierwotnej wskażę, w jaki sposób można w ich przypadku rozumieć funkcję epistemiczną emocji. W kolejnym kroku odwołam się do zagadnienia tzw. przeżycia znaczenia. Na tej podstawie sformułuję hipotezę, co stanowi zarazem główny cel artykułu, że pewna klasa emocji epistemicznych nie tylko współtworzy konteksty intensjonalne, ale stanowi również warunek konstytutywny znaczenia i użycia pojęć.

7 Por. A. Morton, Epistemic emotions, w: The Oxford handbook of philosophy of emotion, ed. P. Goldie, Oxford 2010, 385-399; tenże, Emotion and imagination, Cambridge 2013.

8 Do emocji epistemicznych oprócz poczucia poprawności zalicza się literaturze przedmiotu również m.in. poczucie typu „mam to na końcu języka”, ciekawość, wątpliwość, czy poczucie pewności. Por. S. Arango-Muñoz, K. Michaelian, dz. cyt. 


\section{POCZUCIE BLĘDU I POPRAWNOŚCI}

Nie wydaje się kontrowersyjne przekonanie, że pewnym działaniom towarzyszy lub może towarzyszyć poczucie poprawności lub niepoprawności danego działania'. Przykładem może być poczucie, że dokonaliśmy poprawnego obliczenia w matematyce lub że zachodzi błąd w procesie rozumowania. Podobne przypadki możemy wyodrębnić w kontekstach percepcyjnych: możemy mieć poczucie, że zachodzi pewna niespójność w doświadczeniu percepcyjnym, co może być oznaką zjawiska iluzji lub halucynacji. Nie ulega również wątpliwości, że możemy wyodrębnić elementy emocjonalne w doświadczeniu semantycznym, na przykład gdy ktoś zaczyna rozumieć obcy język, potrafi wychwycić znaczenie poszczególnych obcojęzycznych wyrażeń podczas rozmowy lub dostrzega niezręczne stylistycznie lub składniowo użycie wyrażeń w przypadku języka ojczystego ${ }^{10}$.

Wszystkie te przykłady łączy to, że posiadamy pewne pozbawione wyraźnego uzasadnienia emocje, które wskazują na poprawność lub niepoprawność pewnych procesów umysłowych. Przez brak wyraźnego uzasadnienia rozumiem to, że dane poczucia mogą stanowić motywację dla poszukiwania źródeł adekwatności danych emocji, na przykład dla poszukiwania błędu w rachunkach, ale same rozpoznanie faktu, na przykład błędu w rachunkach, nie stanowi podstawy dla posiadania danych emocji. Mówiąc ściślej, odpowiednie poczucie poprawności lub niepoprawności jest niezależne od rozpoznania racji

9 Por. B. Mangan, Bruce, Taking phenomenology seriously: The "fringe" and its implications for cognitive research, Consciousness and Cognition 2(1983)2, 89-108; tenże, Sensation's ghost: The non-sensory "fringe" of consciousness, Psyche 18(2001)7; V. Thompson, Dual-process theories: A metacognitive perspective, w: Two minds: Dual processes and beyond, ed. J. Evans, K. Frankish, Oxford 2009, 171-195.

10 Por. G. Strawson, Cognitive phenomenology: Real life, w: Cognitive phenomenology, ed. T. Bayne, M. Montague, Oxford 2011, 285-325; B. Mangan, Sensation's ghost: The non-sensory "fringe" of consciousness, dz. cyt. 
dowodowych. Emocje epistemiczne posiadamy lub ich nie posiadamy bez względu na to, czy dostrzegamy powody by je posiadać.

W przypadku emocji epistemicznych, takich jak poczucie poprawności lub niepoprawności, istotne jest to, że wskazuje się tu na poprawność lub niepoprawność realizacji danego procesu umysłowego. Innymi słowy, posiadamy pewne subiektywne doświadczenie, że zaszedł lub nie zaszedł pewien błąd w realizacji działania pewnego mechanizmu umysłowego, na przykład w przypadku rozumowania lub podejmowania decyzji ${ }^{11}$. Dzięki emocjom epistemicznym uzyskujemy informację, że odpowiedni mechanizm umysłowy funkcjonuje, zafunkcjonował lub może zafunkcjonować poprawnie lub niepoprawnie.

O ile jednak stosunkowo łatwo wyodrębnić w doświadczeniu pewne emocje epistemiczne, o tyle trudniej odpowiedzieć na pytanie, co stanowi ich treść - w sensie warunków spełnialności - oraz ich funkcję w systemach poznawczych.

Pierwsza kwestia dotyczy treści. Prima facie wydaje się, że emocje epistemiczne powinny posiadać charakter metareprezentacyjny, to jest powinny stanowić metareprezentacje funkcjonowania odpowiednich stanów reprezentacyjnych. Tak jednak nie jest. Zwróćmy uwagę, że jeżeli zgodzić się na metareprezentacyjny charakter emocji epistemicznych, to napotykamy wówczas problem regresu w nieskończoność co do treści, ponieważ warunki poprawności danych emocji byłyby określone przez metaemocje itd. Innymi słowy, żeby rozstrzygnąć, że odpowiednie emocje epistemiczne są poprawne lub niepoprawne, należałoby odwołać się do innych emocji epistemicznych i tak w nieskończoność. W konsekwencji albo emocje epistemiczne nie posiadałyby treści, albo należałoby znaleźć taki ich opis, który nie zakłada odwoływania się do metareprezentacji ${ }^{12}$.

11 Por. W. de Neys, Bias and conflict, Perspectives on Psychological Science 7(2012)1, 28-38.

12 Por. P. Carruthers, dz. cyt.; J. Proust, Metacognition and metarepresentation: is a self-directed theory of mind a precondition for metacognition?, Synthese 159(2007)2, 
Za drugą charakterystykę treści emocji epistemicznych możemy przyjąć ich brak kryteriów i niedyskursywność. Jak pisałem, możemy posiadać poczucie poprawności lub niepoprawności bez względu na to, czy rozpoznajemy pewne racje uzasadniające posiadanie danego poczucia. Odpowiednie poczucia są również niezależne od umiejętności ich pojęciowego wyrażenia. Mówiąc obrazowo, możemy posiadać poczucie poprawnego gramatycznie użycia danego wyrażenia bez względu na to, czy znamy odpowiednią wyrażoną wprost regułę gramatyczną. Żeby posiadać emocje epistemiczne, nie potrzebujemy ani kryterium, ani możliwości ich pojęciowego opisu.

Druga kwestia dotyczy roli emocji epistemicznych w systemach poznawczych. We współczesnej literaturze przedmiotu dominuje przekonanie, że główną rolą tych pierwszych jest zmniejszanie kosztów informacyjnych i zwiększenie szybkości podejmowania decyzji ${ }^{13}$. Jeżeli przyjąć, że główną funkcją umysłu jest działanie w warunkach niepewności i adekwatne reagowanie na zmieniające się otoczenie, to emocje epistemiczne mogą być skutecznym narzędziem do radzenia sobie z tą niepewnością. Przykładowo poczucie poprawności może przyczyniać się do zwiększenia efektywności oceny odpowiedniego działania lub zdarzenia i adekwatnej reakcji na to działanie lub zdarzenie ${ }^{14}$. Emocje epistemiczne pełniłyby funkcje heurystyczne zwiększające szanse na przeżycie organizmu w danym otoczeniu.

Wydaje się, że nie zachodzi sprzeczność w przypadku takiego ujęcia funkcji emocji epistemicznych. Sama odpowiedź również zdaje się wiarygodna. Jeżeli jednak zgodzić się wyłącznie na to, że emocje epistemiczne pełnią funkcję heurystyczną, przykładowo ułatwiając

271-295; J. Proust, Epistemic agency and metacognition: An externalist view, Proceedings of the Aristotelian Society 108(2008)1, 241-268.

13 Por. A. Morton, Epistemic emotions, dz. cyt.

14 Por. S. Arango-Muñoz, Scaffolded memory and metacognitive feelings, Review of Philosophy and Psychology 4(2013)1, 135-152; J. Proust, Metacognition and metarepresentation: is a self-directed theory of mind a precondition for metacognition?, dz. cyt.; J. Proust, Epistemic agency and metacognition: An externalist view, dz. cyt. 
i przyśpieszając pewne procesy decyzyjne, to nie istnieje dobry powód, dla którego nie miałyby zostać zastąpione przez odpowiednio sprawniejsze narzędzie obliczeniowe. O ile zatem nie istnieje konieczność rezygnacji $z$ twierdzenia o heurystycznej roli emocji, to proponuję rozważyć hipotezę, zgodnie z którą emocje epistemiczne są nie tylko nośnikiem pewnych informacji, ale są one również niezbędne dla systemu ${ }^{15}$. Pośrednią racją, dla której warto przyjąć tę hipotezę, jest fakt, że w historii filozofii wielokrotnie podnoszono kwestię przydatności odwoływania się do emocji, na przykład w przypadku działań moralnych, ale powodem, dla którego wykazywano nieufność w stosunku do tych pierwszych, była ich zawodność. Innymi słowy, posiadamy lepsze narzędzia, na przykład narzędzia logiczne, do podejmowania decyzji i oceny sytuacji. W moim przekonaniu, co postaram się zaprezentować niżej, warto zatem bronić mocniejszej tezy, zgodnie z którą emocje epistemiczne nie tylko pełnią funkcje heurystyczne, ale są warunkiem możliwości poznania umożliwiającym odnoszenie się umysłu do świata. Wyjaśnieniu tego, co to znaczy, poświęcone zostaną kolejne punkty, dotyczące problematyki normatywności pierwotnej i kierowania się regułą.

\section{NORMATYWNOŚĆ PIERWOTNA I PROBLEM KIEROWANIA SIĘ REGUŁA}

Problem treści emocji epistemicznych daje się podsumować w pytaniu, w jaki sposób pogodzić ich niemetareprezentacyjny, pozbawiony kryteriów i niedyskursywny charakter $\mathrm{z}$ ich możliwością odnoszenia się do własnych stanów umysłowych podmiotu oraz poprawnego orzekania o tych stanach. Innymi słowy, możemy zapytać, w jaki sposób emocje epistemiczne odnoszą się do własnych stanów umysłowych oraz skąd wiemy, że nie mylimy się, posiadając odpowiedni stan emocjonalny.

15 Por. G. Brun, D. Kuenzle, A New Role for Emotions in Epistemology?, w: Epistemology and Emotions, dz. cyt., 1-32. 
W przypadku ostatniego pytania możliwe są co najmniej dwie strategie udzielania nań odpowiedzi. Przede wszystkim możemy negować samą zasadność zadawania tego rodzaju pytań. Ukrytą przesłanką tej strategii jest przekonanie, że emocje epistemiczne współtworzą konteksty intensjonalne, ale nie określają treści przekonań. Oznacza to między innymi, że jeżeli formułuję sąd typu: „czuję, że zaszedł błąd w rachunkach", to element emocjonalny odpowiada wyłącznie za subiektywne poczucie „czuję, że”, a nie za to, „że zaszedł błąd w rachunkach". W takim wypadku nie pojawia się pytanie o możliwość błędu, ponieważ choć mogę się mylić, „że zaszedł błąd w rachunkach", to nie mogę się mylić, że mam odpowiednie poczucie typu „czuję, że”.

Pozornie opisana wyżej strategia jest atrakcyjna, ponieważ oddaje potoczną intuicję o niefalsyfikowalności emocji. $Z$ co najmniej dwóch powiązanych ze sobą względów wspomniana strategia jest jednak myląca. Po pierwsze, rodzi się problem natury pojęciowej. Jeżeli wykluczymy możliwość błędu w przypadku emocji epistemicznych, to należałoby również wykluczyć możliwość posiadania treści przez te ostatnie, ponieważ jeżeli $X$ ma posiadać warunki spełnialności, rozumiane jako warunki poprawności lub prawdziwości, to należałoby z konieczności założyć, że $X$ posiada również warunki bycia niepoprawnym lub nieprawdziwym. Mówienie o warunkach spełnialności w sytuacji, w której wykluczamy możliwość warunków bycia niespełnionym, to błąd w pojęciu. Po drugie, jeżeli wykluczyć możliwość posiadania treści przez emocje epistemiczne, to problem rodzi przypisywanie im jakiejkolwiek niemetaforycznie ujętej funkcji epistemicznej w sensie możliwości odwzorowania w zbiór wartości prawdy i fałszu. Możliwość takiego odwzorowania jest konieczna, jeżeli chcemy założyć, że emocje epistemiczne mogą być nośnikiem informacji w sensie semantycznym, a takie założenie musimy przynajmniej móc przyjąć na próbę, jeżeli chcemy rozważyć zaproponowaną przeze mnie hipotezę emocji epistemicznych jako warunku koniecznego znaczenia. 
Druga strategia wiąże się z próbą wskazania takiej własności lub faktu, które pozwoliłyby orzekać o błędności lub poprawności danej emocji epistemicznej. Bez względu na to, jakiego rodzaju miałby być to fakt lub własność, to problem rodzi wówczas dwie kwestie: jak powiązać tę strategię z przekonaniem o nieposiadaniu kryteriów i niedyskursywnym charakterem emocji epistemicznych oraz co mogłoby stanowić owe podstawy błędności lub poprawności. Druga strategia jest jednak o tyle obiecująca, że pozwala przypisywać emocjom odpowiednie role w systemach poznawczych ze względu na posiadanie przez nie treści, a w konsekwencji, że przynajmniej otwiera się droga, aby myśleć o roli emocji epistemicznych w sensie mocniejszym, to jest wykraczającym poza funkcje heurystyczne.

Zwróćmy uwagę, że pytanie o źródło poprawności odpowiednich emocji epistemicznych pozwala rozważyć kwestię treści tych ostatnich w ramach ogólniejszego problemu kierowania się regułą. Jak wiadomo, polega on na trudności wskazania racji, na podstawie której można byłoby rozstrzygnąć, czy - przykładowo - danej operacji matematycznej należałoby przypisać regułę dodawania czy kwodawania ${ }^{16}$. W sformułowaniu ogólnym dotyczy ona m.in. tego, skąd wiemy i na jakiej podstawie orzekamy o błędzie. Moją ambicją nie jest oczywiście próba rozwiązania tego zagadnienia. Wskażę jednak na pewien element tego rozwiązania, który bezpośrednio łączy się z kwestią emocji epistemicznych i pozwoli w konsekwencji rozjaśnić naturę tych ostatnich. Za Hannah Ginsborg ${ }^{17}$ proponuję rozważyć w tym miejscu hipotezę tzw. normatywności pierwotnej (primitive normativity) $^{18}$.

16 Por. S. Kripke, Wittgenstein on Rules and Private Language, Cambridge 1982.

17 Por. H. Ginsborg, Primitive normativity and scepticism about rules, The Journal of Philosophy 108(2011), 227-254.

18 Więcej na temat normatywności pierwotnej por. P. Kozak, Co to jest myślenie? Pojęcia, sądy i percepcja w perspektywie kantowskiej, Warszawa 2015; tenże, Sztuka i myśl, Warszawa 2016. 
Normatywność pierwotną daje się zdefiniować następująco: operacji $\varphi$ możemy przypisać własność normatywności pierwotnej wtedy i tylko wtedy, gdy pomiot $I$ dokonujący operacji $\varphi$ może bezpośrednio, to jest bez odwoływania się do wyrażonej wprost reguły $R$, przypisać $\varphi$ wartość poprawnej lub niepoprawnej realizacji $\varphi$. Przykładem obrazującym daną hipotezę może być dziecko, które uczy się posługiwać wyrażeniem „niebieski”. Pierwszym krokiem, które musi opanować dziecko, jest umiejętność rozdzielania przedmiotów niebieskich i nie-niebieskich. Jeżeli opanuje tę umiejętność, to możemy założyć, że czyni to będąc w posiadaniu pewnego poczucia poprawności swojego działania, to jest dostrzega ono, że poprawnie jest klasyfikować przedmioty niebieskie jako niebieskie i przedmioty nie-niebieskie jako nie-niebieskie, czyli niedyskursywnie rozpoznaje poprawność odpowiedniej klasyfikacji. Nie musimy w tym wypadku zakładać, że dziecko posiada znajomość pewnej wyrażonej wprost reguły. Możemy jednak założyć, że posiadanie pewnej emocji epistemicznej u dziecka zakłada, że posiada ono pojęcie 'niebieski', choć nie musi posiadać znajomości językowego wyrażenia „niebieski”. Mówiąc ściślej, nauka posługiwania się wyrażeniem „niebieski” będzie wyłącznie językową stroną tej podstawowej umiejętności.

Co najważniejsze, tym, co charakteryzuje opisane działanie dziecka, nie jest wyłącznie pewna regularna dyspozycja do dzielenia przedmiotów na niebieskie i nie-niebieskie i przypisywania im nazwy „niebieski” i „nie-niebieski”. Istotne jest to, że dziecko zajmuje wobec swych działań pozycję normatywną. Oznacza to, że jest ono w stanie przypisać swoim działaniom wartość poprawności i niepoprawności. Nie odwołuje się ono przy tym do jakieś formy kryterium lub uzasadnienia rozstrzygających o poprawności lub niepoprawności, ale bezpośrednio i niedyskursywnie dostrzega poprawność danego działania. Co więcej, możliwość przypisania tym działaniom wartości poprawności i niepoprawności jest dla dziecka racją, by odpowiednio działać i by odpowiedniego działania wymagać od innych. 
Oczywiście, jak można łatwo zauważyć, odwołanie się do normatywności pierwotnej niczego jeszcze nie rozwiązuje. Przede wszystkim nie pozwala odpowiedzieć na dwa zarzuty. Po pierwsze, nie wiadomo, jak rozstrzygnąć, czy sprzeczny w stosunku do naszego sąd o poprawności sam jest poprawny, czy nie jest. Nie posiadamy żadnych kryteriów, aby rozstrzygać o poprawności działań lub sądów w przypadku ewentualnego konfliktu przekonań. Podmiot I może orzekać, że $2+2=4 \mathrm{z}$ takim samym poczuciem poprawności, jak podmiot $J$, który orzeka, że $2+2=5$. W konsekwencji, nie istniałby sposób, aby sensownie mówić o jakiejkolwiek - wykraczającej poza subiektywne poczucie - poprawności. Po drugie, wciąż otwartym pozostaje pytanie, dlaczego uznajemy takie, a nie inne sądy za poprawne. Ostatecznie nasza emocjonalna reakcja może być błędna. Innymi słowy, odwołanie się do niedyskursywnych odczuć orzekających o poprawności lub niepoprawności realizacji odpowiednich dyspozycji poznawczych lub praktycznych niczego nie rozstrzyga, ponieważ wciąż możemy zasadnie pytać, na jakiej podstawie wiemy, że nasze odczucia nas nie zwodzą.

Powodem, dla którego przywołuję wspomnianą hipotezę normatywności pierwotnej, nie jest jednak to, że stanowi ono rozwiązanie problemu kierowania się regułą, ale to, że pragnę wskazać i zachować dwie istotne i powiązane ze sobą intuicje. Po pierwsze, odwołanie się do pozycji normatywnej pozwala w lepszy sposób uchwycić fenomen niefalsyfikowalności emocji epistemicznych oraz ich niemetareprezentacyjny charakter. Nie musimy zakładać, że nie możemy się pomylić $\mathrm{w}$ kwestii posiadania odpowiedniego stanu emocjonalnego. Nie musimy również twierdzić, że emocje epistemiczne stanowią metareprezentacje odpowiednich reprezentacyjnych stanów umysłowych. Wystarczy, że potraktujemy emocje epistemiczne jako aspekt kryteriów lub miar, za pomocą których opisujemy lub oceniamy działania nasze lub innych. Nie oznacza to, że dana miara nie może być błędna - ostatecznie zawsze można zastąpić ją inną, bardziej użyteczną, tak jak sposób opisu przestrzeni fizycznej może dokonywać 
się zarówno przy pomocy miary trój-, jak i n-wymiarowej. Oznacza to jednak, że z przyczyn logicznych nie pojawia się pytanie, skąd wiemy, że mylimy się w kwestii posiadania odpowiednich emocji epistemicznych, tak jak nonsensowne jest pytanie, skąd wiemy, że miara metra mierzy metr.

Po drugie, odwołanie się do emocji epistemicznych w kontekście problemu kierowania się regułą implikuje, że zdolność kierowania się regułą oraz możliwość odnoszenia się naszych pojęć do świata zakładają, że posiadamy niedyskursywne poczucie poprawności operowania określonymi pojęciami i regułami, ewentualnie, że jesteśmy w stanie bezpośrednio dostrzec tę poprawność. Nie jest zatem tak, że odwołanie się do poczucia poprawności rozwiązuje problem kierowania się regułą. Twierdzę jednak, że odwołanie się do podmiotowych i niedyskursywnych emocji epistemicznych stanowi element tego rozwiązania. Co więcej, w następnym punkcie postaram się przedstawić hipotezę, zgodnie z którą wspomniane poczucie poprawności i niepoprawności stanowi warunek konstytutywny poznania, mówiąc ściślej, konstytuuje podmiotowy aspekt aktów kierowania się regułą i odnoszenia się stanów umysłowych do świata.

\section{3. ŚLEPOTA NA ASPEKTY I PRZEŻYCIE ZNACZENIA}

W poprzednim punkcie argumentowałem, że kwestia treści i funkcji emocji epistemicznych daje się powiązać z ogólnie rozumianym problemem kierowania się regułą. Twierdziłem również, że nie jest jasne, czym jest określone poczucie poprawności i niepoprawności oraz jaką rolę pełni ono w aktach kierowania się regułą i odnoszenia się stanów umysłowych do świata. W poniższym punkcie proponuję przyjrzeć się temu problemowi od strony zagadnienia tzw. ślepoty na aspekty oraz przeżycia znaczenia. Twierdzę, że umieszczenie w tym kontekście pytania o emocje epistemiczne pozwoli lepiej zrozumieć naturę i funkcję tych ostatnich. 


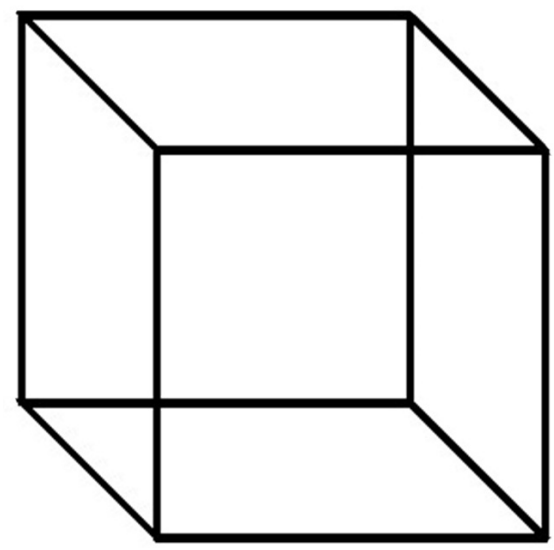

Rys. 1

W ujęciu Wittgensteina ${ }^{19}$ pojęcie „ślepoty na aspekty” oznacza brak umiejętności dostrzeżenia poszczególnych aspektów danych przedstawień, takich jak dwa różne przedstawienia sześcianu Neckera (rys. 1), czy dwóch różnych aspektów obrazu kaczko-królika. Innymi słowy, osoba ślepa na aspekty nie potrafi rozpoznać, przykładowo, dwóch różnych obrazów sześcianu Neckera jako obrazu jednego pojęcia sześcianu Neckera lub obrazu kaczki lub królika jako kaczko-królika. Mówiąc ściślej, ślepota na aspekty polegałaby na braku umiejętności takiej zmiany sposobu widzenia, która umożliwiałaby przejście od jednej interpretacji obrazu sześcianu Neckera do innej interpretacji lub przejście od obrazu kaczki albo królika do przedstawienia kaczki oraz królika. Ślepotę na aspekty w języku możemy rozumieć między innymi jako brak umiejętności rozpoznania wyrażenia „lecz” jako spójnika oraz czasownika. Osoba, która „nie przeżywałaby znaczenia słów", nie byłaby w stanie doświadczyć „przejścia” od wyrażenia „lecz” w funkcji spójnika do tego samego

19 Por. L. Wittgenstein, Dociekania filozoficzne, przeł. B. Wolniewicz, Warszawa 2004, 299 i n.; Ch. Wenzel, On Wittgenstein's Notion of Meaning-Blindness: Its Subjective, Objective and Aesthetic Aspects, Philosophical Investigations 33/3(2010), 201-219. 
wyrażenia w funkcji czasownika i nie dostrzegałaby tożsamości, która pod pewnym nietrywialnym względem łączy oba wyrażenia.

Zwróćmy uwagę, że ślepota na aspekty i przeżycie znaczenia dzielą istotne własności z emocjami epistemicznymi. Przede wszystkim percepcja łączy się tu ze znaczeniem, to jest dostrzegamy odpowiednie znaczenie bezpośrednio, nie odwołując się do racji pośredniczących lub kryteriów rozstrzygających o znaczeniu. W przypadku sześcianu Neckera bezpośrednio widzimy odpowiednią interpretację sześcianu, to jest rozpoznajemy sześcian jako posiadający odpowiednie rogi bliżej lub dalej. Nie możemy danej interpretacji wywnioskować, ale możemy ją dostrzec tak samo, jak możemy dostrzec poprawność odpowiedniego użycia wyrażenia „lecz”. Innymi słowy, widzimy lub nie widzimy danej interpretacji sześcianu, tak jak „widzimy” lub „nie widzimy” danego znaczenia wyrażenia „lecz”. Analogicznie, możemy rozpoznawać zieleń lub nie rozpoznawać zieleni, ale nie możemy rozpoznawać fenomenalnej jakości zieleni, odwołując się do pośredniczącego opisu, na przykład opisu neurofizjologicznego lub psychologicznego doświadczenia zieleni.

Istotne są tu dwie kwestie. Po pierwsze, „przeżycie znaczenia” nie może opierać się wyłącznie na zewnętrznych i przedmiotowych kryteriach, ponieważ, przykładowo, obraz kaczko-królika jest jedynym i przedmiotowo tym samym obrazem tak w interpretacji tego obrazu jako kaczki, jak i w interpretacji tego obrazu jako królika. Analogicznie w przypadku sześcianu Neckera: możemy dostrzegać dwie różne interpretacje sześcianu, ale przedmiotowo jest to jeden i ten sam obraz sześcianu. Skąd zatem wiemy, że spostrzegamy odpowiedni aspekt? Kluczowe wydaje się tu odwołanie się do emocji epistemicznych jako pewnych niedyskursywnych i subiektywnych stanów wewnętrznych umożliwiających przejście między różnymi aspektami, to jest umożliwiające dostrzeganie dwóch różnych aspektów jednego i tego samego obrazu.

Po drugie, odpowiednie wrażenie lub przeżycie nie jest czymś dołączonym do słów lub aspektów, ale jest nierozdzielne $\mathrm{z}$ danymi 
słowami lub aspektami. Nie zakładamy tu obecności jakiejś dodatkowej formy metareprezentacji nałożonej na akt widzenia danego aspektu kaczko-królika lub sześcianu Neckera, na przykład jakiejś formy odwołania się do pośredniczącego emocjonalnego kryterium, ale odpowiednie niedyskursywne przeżycie jest wymiarem ogólnej umiejętności rozpoznawania aspektów. Innymi słowy, nie rozpoznajemy poprawności zastosowania danej reguły, pojęcia lub użycia wyrażenia językowego w wyniku odwołania się do kryterium orzekającego o poprawności danego użycia. To samej operacji zastosowania reguly towarzyszy od strony subiektywnej i podmiotowej niedyskursywna świadomość poprawności realizacji danej operacji. Poprawność użycia danej reguły lub pojęcia „widzimy” w samym zastosowaniu danej reguły lub pojęcia, tak jak dostrzegamy dany aspekt rzeczy. Nie oznacza to, że dane afektualne „przeżycie znaczenia" należy utożsamiać z samym znaczeniem. Oznacza to jednak, że niedyskursywny, subiektywny i podmiotowy aspekt znaczenia jest warunkiem koniecznym dyskursywnego, przedmiotowego i obiektywnego znaczenia. Mówiąc inaczej, aby nasze sądy mogły posiadać pojęciową treść, musimy nauczyć się rozpoznawać tę treść, a owa nauka to nic innego, jak opanowanie określonej niedyskursywnej sztuki widzenia czy też rozpoznawania określonych aspektów rzeczy lub użycia wyrażeń.

Pośrednim powodem, dla którego warto rozważyć taką hipotezę, jest fakt, że jeżeli naszym podporządkowaniom przedstawień pod pojęcia nie towarzyszyłoby poczucie poprawności tych operacji - na przykład nie moglibyśmy mieć pewności, co oznacza wyrażenie „stół”, to jest czy oznacza w języku polskim stół, krzesło, czy cokolwiek innego - to o żadnym wyznaczeniu znaczenia nie mogłoby być mowy. Nie dałoby się wówczas wskazać warunków poprawności użycia danych pojęć. Mówiąc jeszcze inaczej, gdyby w żadnym możliwym świecie $W$ nie istniał taki podmiot, którego sądom towarzyszyłoby niedyskursywne poczucie poprawności użycia danych pojęć, to nie istniałby taki możliwy świat $W$, w którym dałoby się wyznaczyć 
związek konieczny między pojęciem a odniesieniem, ponieważ nie istniałaby możliwość orzekania o poprawnym lub niepoprawnym użyciu danego pojęcia. Jest to istotna uwaga, ponieważ pozwala ona twierdzić, że emocje epistemiczne są warunkiem konstytuującym możliwość znaczenia i użycia pojęć. Mówiąc ściślej, niedyskursywne poczucie poprawności nie tylko jest niezależne od rozpoznania wyrażonych wprost reguł lub kryterium, ale to warunkiem koniecznym reguły lub kryterium jest obecność odpowiedniego poczucia poprawności.

\section{EMOCJE EPISTEMICZNE I TEORIA ZNACZENIA}

W poprzednim punkcie zaproponowałem interpretację, zgodnie z którą emocje epistemiczne stanowią warunek konieczny możliwości odnoszenia się naszych pojęć do świata. Nie oznacza to jednak, że jest to warunek wystarczający. Wydaje się jasne, na co zwracałem uwagę w części poświęconej normatywności pierwotnej, że nie możemy znaczenia oraz rozpoznawania aspektów opisywać wyłącznie przez odwołanie się do niedyskursywnych i subiektywnych doznań. W konsekwencji, o poprawności odpowiednich raportów obserwacyjnych nie może decydować wyłącznie poczucie poprawności, ale należy móc wskazać odpowiednie zewnętrzne, pojęciowe i przedmiotowe kryteria poprawności danego rozpoznania. Mówiąc inaczej, aby poprawnie rozpoznawać dany aspekt, ten ostatni należy móc pokazać lub opisać w sensie wskazania na pewne przedmiotowe własności danego aspektu, to jest na obiektywne kryteria uzasadniające poprawność konstrukcji danego przedstawienia.

Trudność polega w tym wypadku na zrozumieniu tego, jaka relacja wiąże ze sobą wewnętrzne stany umysłowe będące subiektywną i niedyskursywną stroną postrzegania aspektów oraz obiektywne i pojęciowe kryteria, których założenie jest niezbędne w rozpoznawaniu aspektów. Jeżeli wspomniane stany wewnętrzne są niedyskursywne i subiektywne, to prima facie wydaje się, że nie moga 
wchodzić w relacje z wyrażalnymi pojęciowo i obiektywnymi kryteriami. $Z$ drugiej strony, taki związek jest wymagany, jeżeli chcemy zachować możliwość rozpoznawania aspektów i znaczenia. Jako ilustracja tego problemu niech posłuży w naszym przypadku przykład doświadczenia estetycznego. Interpretując wiersz, możemy, z jednej strony, wskazać obiektywne kryteria poprawności odczytania danego wiersza, np. odpowiedni rytm, spójność stylistyczną i tematyczną lub zgodność gatunkową danego utworu. $Z$ drugiej strony, „widzimy” lub „czujemy” daną poprawność, to jest posiadamy odpowiednie subiektywne i niedyskursywne poczucie zrozumienia danego utworu, co uwidacznia się szczególnie w sytuacjach dzieł niestandardowych i „nieoczywistych”, których odczytanie wymaga specjalnego nastawienia poznawczego, jak w przypadku formalizmu w poezji. Pomocny może być tu przykład słynnego pięciowiersza Aleksieja Kruczonycha z 1913 roku:

dyr but szczyl

ubieszszczur

skum

wy so bu

rtez

Poprawne odczytanie wiersza Kruczonycha zakłada wprawdzie z konieczności możliwość odwołania się do jakiejś formy zewnętrznego wzoru, w tym wypadku kryterium fonetyki języka rosyjskiego, której to istota, zgodnie z zamysłem autora, miałaby być wyrażona w wierszu. Czytelnik musi jednak posiadać wpierw niedyskursywną umiejętność rozpoznania odpowiedniego wzoru lub standardu poprawności, to jest musi móc rozpoznawać taki, a nie inny wzorzec lub standard poprawności jako adekwatny. $\mathrm{W}$ podanym wypadku musi móc odczytać dany wiersz z odpowiednim nastawieniem poznawczym, który umożliwi mu rozpoznanie takiej istotnej własności, która konstytuowałaby poprawność danego wiersza. Przy czym, co pragnę zaznaczyć, owa umiejętność rozpoznawania poprawnego wzoru lub standardu poprawności logicznie poprzedza 
podporządkowanie treści wiersza pod odpowiedni wzór lub standard, ponieważ aby móc przypisać określone własności danemu wierszowi $\mathrm{z}$ racji podporządkowania pod wzór $X$, muszę móc rozpoznawać, że wiersz podpada pod wzór $X$, a nie pod $Y$. Kluczowe wydaje się tu subiektywne doświadczenie, polegające na dostrzeżeniu poprawności danego wiersza odczytywanego z perspektywy samej formy fonetycznej wiersza, to jest subiektywne doświadczenie, że dany wiersz tworzy pewną kierowaną regułami całość, podpadając pod jakiś, niekoniecznie wyrażony wprost, wzór, standard lub pojęcie. W tym przypadku niedyskursywne rozpoznanie brzmieniowej strony wiersza Kruczonycha, ewentualnie odczytanie wiersza z odpowiednim nastawieniem poznawczym, umożliwia mówienia o poprawności konstrukcji wiersza Kruczonycha.

$\mathrm{Z}$ drugiej strony, nie wystarczy subiektywne odczucie poprawności konstrukcji wiersza Kruczonycha, aby mówić o poprawności danego wiersza. Należy móc wskazać określony obiektywny i dający się dyskursywnie wyrazić wzór, w tym wypadku wzór fonetyki języka rosyjskiego. W przeciwnym wypadku wspomniane odczucie poprawności byłoby nierozróżnialne $\mathrm{z}$ wyrażeniem subiektywnej opinii, a zatem nie byłoby można mówić o żadnej intersubiektywnie ważnej poprawności wiersza.

Rozwiązaniem powyższej trudności jest obserwacja, że pomiędzy obiema stronami, subiektywną i niedyskursywną oraz obiektywną i pojęciową, nie zachodzi różnica rodzajowa, ale modalna, to znaczy elementy subiektywny i niedyskursywny oraz obiektywny i pojęciowy stanowią dwie strony znaczenia. Nie jest zatem tak, że o poprawności danego wiersza decydować będzie wyłącznie zgodność $z$ danymi wymogami formalnymi lub - z drugiej strony - wyłącznie zgodność z jakąś formą emocjonalnego wczucia się w treść danego wiersza. Jest raczej tak, że obie strony - subiektywna i obiektywna - są nierozróżnialne w bezpośrednim odbiorze wiersza, mówiąc ściślej, dają się rozróżnić jedynie modalnie. 
W konsekwencji możemy potraktować emocje epistemiczne jako jeden $\mathrm{z}$ wymiarów ogólnej umiejętności posługiwania się pojęciami i kierowania się regułą. Nie stanowią one pewnego dodatku do tej umiejętności, ale są jej aspektem. Zaletą takiej interpretacji jest to, $\dot{z} \mathrm{e}-\mathrm{tak}$ jak w przypadku, gdy potraktowano czas nie jako oddzielną kategorię, ale jako wymiar czasoprzestrzeni - znika szereg opisanych wcześniej trudności. W takim ujęciu nie pojawia się problem metareprezentacji, ponieważ emocje epistemiczne nie są dodatkowym aktem nałożonym na operacje pojęciowe, ale jedną ze stron, z których możemy spoglądać na te operacje. Nie zachodzi również konieczność wskazywania kryterium poprawności emocji epistemicznych, ponieważ to same emocje stanowią wymiar określonych kryteriów. Daje się również obronić przesłanka o niezbędnej, a nie wyłącznie heurystycznej roli emocji w poznaniu. Zaproponowana przeze mnie interpretacja natury emocji epistemicznych daleka jest oczywiście od wyczerpującej. Wskazałem również jedynie pośrednie powody, dla której warto ją przyjąć. Nie stanowi ona jeszcze pełnego wyjaśnienia treści i roli emocji epistemicznych w systemach poznawczych, a z pewnością nie jest to takie wyjaśnienie, na które każdy może się zgodzić. Mam jednak nadzieję, że jest to takie wyjaśnienie, z którym można podjąć dyskusję.

\section{BIBLIOGRAFIA}

Arango-Muñoz S., Michaelian K., Epistemic feelings, epistemic emotions: Review and introduction to the focus section, Philosophical Inquiries 2(2014)1, 97-122.

Arango-Muñoz S., Scaffolded memory and metacognitive feelings, Review of Philosophy and Psychology 4(2013)1, 135-152.

Arango-Muñoz S., The nature of epistemic feelings, Philosophical Psychology 27(2014)2, 193-211.

Bennett M.R., Hacker P.M.S., Philosophical Foundations of Neuroscience, Blackwell Publishing, Oxford 2003. 
Brun G., Kuenzle D., A New Role for Emotions in Epistemology?, w: Epistemology and emotions, eds. G. Brun, U. Doğuoğlu, D. Kuenzle, Routledge, New York 2016, 1-32.

Carruthers P., Are epistemic emotions metacognitive?, Philosophical Psychology (2016), DOI: 10.1080/09515089.2016.1262536.

Dąbrowski A., Wptyw emocji na poznanie, Przegląd Filozoficzny - Nowa Seria 3(2012), 315-335.

Davidson D., Rational animals, Dialectica 36(1982), 317-327.

De Neys W., Bias and conflict, Perspectives on Psychological Science 7(2012)1, 28-38.

Dokic J., Seeds of self-knowledge: noetic feelings and metacognition, w: Foundations of metacognition, ed. M.J. Beran, J.L. Brandl, J. Perner, J. Proust, Oxford University Press, Oxford 2012, 302-321.

Ginsborg H., Primitive normativity and scepticism about rules, The Journal of Philosophy 108(2011), 227-254.

Goodman N., Languages of Art. An Approach to a Theory of Symbols, 2nd edition., Hackett, Indianapolis 1976.

Kozak P., Co to jest myślenie? Pojęcia, sady i percepcja w perspektywie kantowskiej, Wydawnictwo Naukowe Scholar, Warszawa 2015.

Kozak P., Sztuka i myśl, NCK, Warszawa 2016.

Kripke S., Wittgenstein on Rules and Private Language, Harvard University Press, Oxford 1982.

Mangan B., Sensation's ghost: The non-sensory "fringe" of consciousness, Psyche 18(2001)7.

Mangan B., Taking phenomenology seriously: The "fringe" and its implications for cognitive research, Consciousness and Cognition 2(1993)2, 89-108.

Morton A., Emotion and imagination, Polity, Cambridge 2013.

Morton A., Epistemic emotions, w: The Oxford handbook of philosophy of emotion, ed. P. Goldie, Oxford University Press, Oxford 2010, 385-399.

Proust J., Epistemic agency and metacognition: An externalist view, Proceedings of the Aristotelian Society 108(2008)1, 241-268.

Proust J., Is there a sense of agency for thought?, w: Mental actions and agency, ed. L. O'Brien, M. Soteriou, Oxford University Press, Oxford 2009, 253-279.

Proust J., Metacognition and metarepresentation: is a self-directed theory of mind a precondition for metacognition?, Synthese 159(2007)2, 271-295.

Schlick M., Über das Fundament der Erkenntnis, Erkenntnis 4(1934), 79-99.

Sousa de R., Epistemic feelings, w: Epistemology and emotions, ed. G. Brun, et.al., Routledge, New York 2016, 185-204. 
Strawson G., Cognitive phenomenology: Real life, w: Cognitive phenomenology, ed. T. Bayne, M. Montague, Oxford University Press, Oxford 2011, 285-325. Thompson V., Dual-process theories: A metacognitive perspective, w: In two minds: Dual processes and beyond, ed. J. Evans, K. Frankish, Oxford University Press, Oxford 2009, 171-195.

Wenzel C. On Wittgenstein's Notion of Meaning-Blindness: Its Subjective, Objective and Aesthetic Aspects, Philosophical Investigations 33(2010)3, 201-219.

Wittgenstein L., Dociekania fllozoficzne, przeł. B. Wolniewicz, Wyd. Naukowe PWN, Warszawa 2004.

\title{
EPISTEMIC EMOTIONS AND NORMATIVITY, OR HOW TO LEARN TO LOVE THE THEORY OF MEANING
}

\begin{abstract}
The aim of this paper is to discuss the content and cognitive function of epistemic emotions such as feelings of correctness and incorrectness. I claim that a proper explanation of such feelings should take into consideration the non-metarepresentational, non-criterial, and non-discursive character of epistemic emotions. With reference to the issue of primitive normativity and rule-following, I argue that we can connect epistemic emotions with the problem of meaning and claim that a specific class of epistemic emotions, i.e. feelings of correctness and incorrectness, is a necessary condition of meaning.
\end{abstract}

Keywords: epistemic emotions; primitive normativity; rule-following; content; meaning

Artykuł powstał w ramach grantu Narodowego Centrum Nauki nr 2015/19/D/HS1/02426.

PIOTR KoZAK

piotr.kozak1@gmail.com

Uniwersytet Warszawski, Instytut Filozofii

Krakowskie Przedmieście 3, 00-047 Warszawa

DOI:10.21697/spch.2018.54.1.15 